\title{
Analysis of Students' Critical and Creative Thinking Style and Cognitive Ability on Chemistry
}

\author{
Abdul Hamid \\ Chemistry Education Department, Teacher Training and Education Faculty, \\ Universitas Lambung Mangkurat \\ hamidkimia123@gmail.com \\ ahamid_kimia@unlam,ac.id
}

\begin{abstract}
This study aimed to determine chemistry education students' style of critical and creative thinking as well as cognitive abilities related to acid-base materials. The research method applied in this study was survey to identify the students' style of critical and creative thinking as well as cognitive abilities. Instructional process was conducted by using Student Center Learning (SCL). The sample consisted of 30 students ( 24 females and 6 males). The data were collected by using open-ended questions related to critical and creative thinking and Yanpiawcritical Creative Styles (YCCS ) test. The research showed that no student had superior creative thinking style category $(0 \%), 20 \%$ of the students were categorized having creative thinking style (medium category), $46.66 \%$ had critical thinking, and $33.34 \%$ had superior critical thinking. Students' academic achievement showed that only $26.66 \%$ of the students have the interpretation critical thinking category, analysis critical thinking category $(20 \%)$ and no student has the originality of creative thinking category. Based on data analysis, it can be concluded that the students' critical and creative thinking styles have the relationship with cognitive ability.
\end{abstract}

Keywords — critical thinking; creativity; cognitive abilities; acids and bases

\section{INTRODUCTION}

Humans are always challenged to be tough and resilient in facing rapidly changing situation. Toughness and tenacity are not enough if the ability to solve problems does not exist. Capability requires ability to think critically and creatively. According to [1], the success of the individual's life is largely determined by its ability to critically and creatively solve problems. Critical thinking can cover the concept of decision-making, strategic planning, scientific process, and critical problem solving. Thinking implies a decision-making process that is full of judgment and conducted independently. Critical thinking skill is an essential ability that to life and work, and it functions effectively in all other aspects of life [2]. Critical thinking is an important process, focused, and obviously used in mental activities such as solving problems, making decisions, analyzing assumptions, and conducting scientific research. Reference [3] stated that core critical thinking is a detailed description of a number of characteristics that include analysis, inference, explanation, evaluation, selfregulation, and interpretation. In addition to critical thinking to cope with life in the $21^{\text {st }}$ century, creative thinking is also required. Creative thinking is an ability to create something new with specificity. According to [4], creative potential can be accessed in four components, namely (1) fluency, which is the ability to generate a number of ideas (2) originality, which is the ability to generate unique ideas out of the ordinary, (3) flexibility, which is the ability to generate various ideas, and (4) elaboration, which is the ability to develop an idea or issue. Creative people can look at a problem from different perspectives. Perspective thus allows individuals to obtain various alternative solutions appropriate to complete problems. Problems will be solved easily if students used to be trained to think critically and creatively in learning through problem solving. Critical and creative thinking can be trained in schools through the learning process. This process can be implemented with Student Center Learning (SCL).

\section{METHOD}

Method used in this research was survey method to determine students' style of critical thinking and creative chemistry as well as the cognitive abilities during the implementation of Student Center Leaning (SCL). SCL is a learning strategy that puts students as active and independent learners (subjects) with a psychological condition as adult learners. Project-based learning was given to 30 students (24 females and 6 males) at the end of the learning session on the evaluation for both critical and creative thinking. The data were collected using Yanpiaw-critical Creative Styles (YCCS) test. This instrument can find a person's style of critical thinking and creative person. Knowing thinking style will assist in identifying the strengths and weaknesses of thought [5]. These instruments have been standardized by the instruments of critical thinking and creative thinking such as Watson-Glaser Critical Thinking and the Torrance Tests of Creative Thinking (TTCT). Scoring of Yanpiaw-critical Creative Styles (YCCS) test was based on the total points of a circle divided by the number of circles (no matter the number of items).

\section{RESULTS AND DISCUSSION}

The data from the survey using Yanpiaw-critical Creative Styles (YCCS) test were collected and calculated to determine the students' scores. The socres were subsequently analyzed and presented in Table I. Based on Table I, the result of $0 \%$ for superior creative thinking indicates that the chemical education students have not been able to learn quickly and effectively through a critical and creative approach. Their general style of 
creative and critical thinking was medium with the percentage of $46.66 \%$. Furthermore $20 \%$ of students think creatively and $33.34 \%$ of students think critically. Students with superior critical and creative thinking are hardly found $(0 \%)$. This condition is very rare as has been done in previous studies by researchers at senior high school. Thus, it can be assumed that the chemical education students will have difficulty in solving problems related to the higher-level thinking such as critical and creative thinking because according to [6] a person's thinking style can predict thinking skills such as critical thinking skill.

TABLE I. Data OF Chemical EdUCATION StUdents’ Style OF CRITICAL THINKING AND CREATIVE THINKING IN BANJARMASIN

\begin{tabular}{llll}
\hline Criteria & $\begin{array}{l}\text { Qualifications } \\
\text { thinking style }\end{array}$ & Score range & Percentage \\
\hline $\mathrm{A}$ & Superior creative thinking & $1.002: 00$ & $0 \%$ \\
\hline $\mathrm{B}$ & Creative thinking & $2,04.51$ & $20.00 \%$ \\
\hline $\mathrm{C}$ & Medium thinking & $4.52-5.51$ & $46.66 \%$ \\
\hline $\mathrm{D}$ & Critical thinking & $5.52-8.00$ & $33.34 \%$ \\
\hline $\mathrm{E}$ & Superior critical thinking & 8.01 to 9.00 & $0 \%$ \\
\hline
\end{tabular}

To see more about the link between thinking styles and cognitive ability, the collected data shown in Table II can be observed. Based on the analysis of the students' answers, $26.66 \%$ of students (8 students) showed critical thinking indicator of interpretation.

TABLE II. COGNITIVE ABILITY OF STUDENTS IN ANSWERING QUESTIONS CRITICALLY AND CREATIVELY

\begin{tabular}{llll}
\hline No & qualifications matter & $\begin{array}{l}\text { Number } \\
\text { students } \\
\text { answered } \\
\text { correctly }\end{array}$ & $\begin{array}{c}\text { of persentase } \\
\text { who }\end{array}$ \\
\hline 1 & Critical thinking(Interpretation) & 8 & $26.66 \%$ \\
\hline 2 & Critical thinking (Analysis) & 6 & $20.00 \%$ \\
\hline 3 & Creative thinking (Originality) & 0 & $0 \%$ \\
\hline
\end{tabular}

The example of students' answer to interpret and portray problem-solving abilities can be seen from Fig. 1. Based on Fig. $1,26.66 \%$ of the students are able to think critically in interpreting and describing the problem solving through chemical reactions. Moreover, the ability of students for analysis indicator shows about $20 \%$. Therefore, the percentage of students who have critical thinking was $46.66 \%$ (14 students). If related to the thinking styles of students, there are 6 students who have critical thinking, 2 students have creative thinking and 3 students have medium level of thinking.

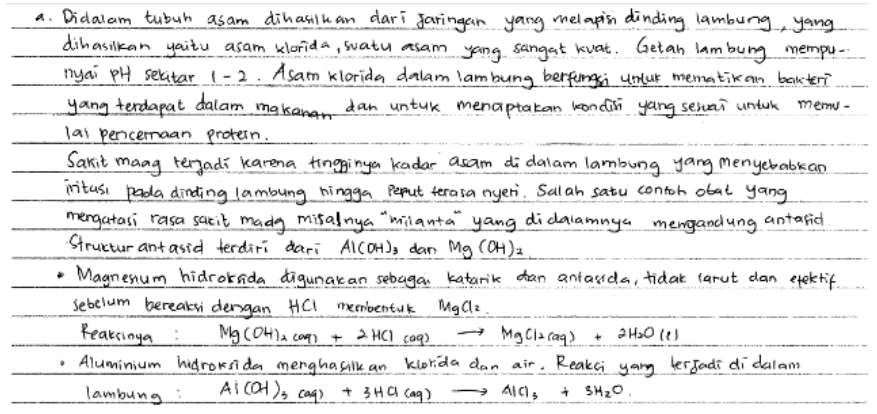

Fig. 1. Students' correct answer on the interpretation indicator of critical thinking

It is hardly to find students who possess cognitive abilities in critical thinking have the style of critical thinking. This is according to what is disclosed by [7] between critical thinking ability of the agricultural university students and their academic achievement in Missouri. Moreover, from the collected data, the students who are not able to answer questions related to the higher-level thinking or critical and creative thinking were $53.34 \%$. The students' weakness is that they do not have a deep understanding of acid-base reactions although they have studied the material since high school. They are only used to memorize formulas without comprehending the material deeply. The example of incorrect answers is shown in Fig. 2.

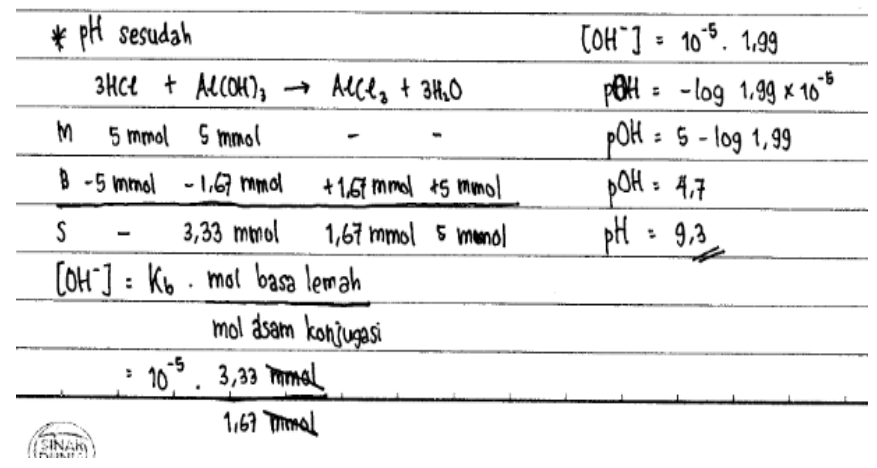

Fig. 2. Students' incorrect answer on analysis indicator of critical thinking

Based on Fig. 2, the students do not understand very well about acids and bases. Their analysis is still weak because they are not able to distinguish between the buffer and hydrolysis so that the $\mathrm{pH}$ calculation becomes wrong. This circumstance is in line with the result of interviews and questionnaires which show that almost all of the students stated that this happened because the given problems are very different from the given example even though in principle the problems are the same. This also indcates that the students are not familiar to perform complex cognitive. If they can only do the test questions which are similar to the example, it shows that students are less creative. Furthermore, no students are able to think creatively by showing originality (novelty). It might be because the ability of students who have a style of creative thinking to answer creatively is still low as fluency and clarity indicators are similar to question no 1 and 2. Ability to think creatively with originality indicator is 
quite difficult for students. It can be seen from the example of students' answer in Fig. 3.

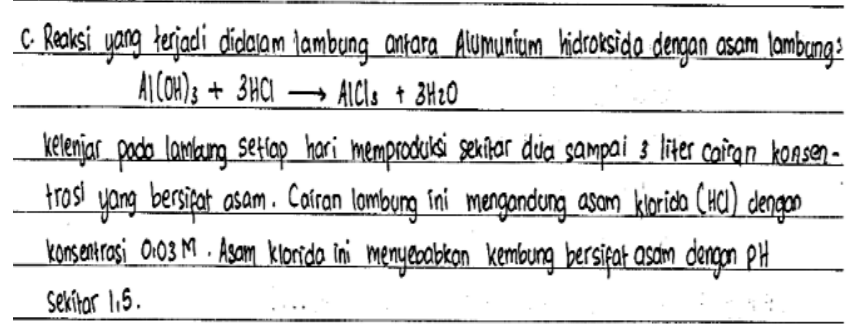

Fig. 3. Students' answer on originality indicator of creative thinking

According to Fig. 3, it can be seen that the students have not been able to think out of the usual way because they focus on the existing examples in the previous questions, while the question actually requires a different answer from the previous question. This shows lack of the students' creative thinking which needs to be developed. The analysis of the data in this research demonstrated that the ability of students to answer with critical thinking was only $46.66 \%$ and the remaining $53.34 \%$ was not able to answer with the high-level thinking skills. Accordingly, it is necessary to find a learning model which can train critical and creative thinking to improve higher-level thinking in order to face current $21^{\text {st }}$ century. This process will be improved more effectively if there is the role of the community, teachers, and parents [8]. Furthermore, the weakness of this research is that it did not involve matters relating to indicators of fluency and clarity for creative thinking to see the cognitive abilities of students, so these indicators need to be studied further in advanced research.

\section{CONCLUSION}

Based on the research results and discussion, it could be concluded that chemical education students do not have the category of superior creative thinking style $(0 \%)$. There are $20 \%$ of the students who have creative thinking styles, $46.66 \%$ having medium thinking style and $33.34 \%$ having critical thinking. No student has superior critical thinking. Cognitive outcomes showed that only $26.66 \%$ of the students have interpretation category of critical thinking, $20 \%$ have analysis category of critical thinking and no student has the originality category of creative thinking. Students' critical and creative thinking styles link to cognitive ability to think critically and creatively.

\section{REFERENCES}

[1] Alexander, KD, Effects of Instruction in Creative Problem Solving on Cocnition, Creativity, and Satisfaction Among Ninth Grade Students In. 2007.

[2] Patrick, "Thinking Critically: An introduction" Working Paper availlble online at http: //www.patrick konions.org/does/academic / 2009\% 20\% 20 critically.pdf think. 2009.

[3] Facione, PA, "The Disposition Toward Critical Thinking: I ts Character,Measurement, and Relationship to Critical Thinking Skill”,@ Informal Logic, Vol 20, No 1 (2000) pp 61-84.
[4] Runco, A., Millar.G, Acar.S, Cramond, B., "Torrance tests of creative thinking as predictors of personal and public achievement: a fifty-year follow-up". Creativity research journal, Vol 22 (4), 1-8, 2010.

[5] Chua, YP Creative and Critical Thinking Styles. Serdang: Universiti Putra Malaysia Press, 2004.

[6] Abdi, A, "A Study on the relation of thingking styles of students andtheir skill “ Critical thingking, Social and Behavioral Sciences, vol 47, pp $1719-1723,2012$.

[7] Burris, S, "An investigation of the critical thinking ability of secondary agriculture students", Journal of Southern Agricultural Education Research 18 Volume 56, Number 1, 2006.

[8] Aharia, S., Samah, BA, Salleh, Wahiza, N, Zaremohzzabieh.Z, "Deepening critical thinking skills through civic engagementin Malaysian higher education”, Thinking Skills and Creativity 22, pp121-128, 2016. 